Başvuru Tarihi: 10.03.2017 Received Date: 10.03.2017

Yayına Kabul Tarihi: 11.06.2017 Accepted Date: 11.06.2017

Yayınlanma Tarihi: 31.07.2017 Published Date: 31.07.2017
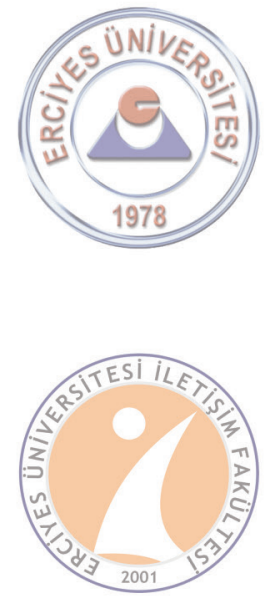

akademia 
ISSN:1308-3198

Erciyes İletişim Dergisi akademia 2017

Cilt (Volume): 5, Say1 (Number): 2, (82-99)
Ali Murat KIRIK (Yrd. Doç. Dr.)

Marmara Üniversitesi İletișim Fakültesi murat.kirik@marmara.edu.tr

Nazlı YAZICI

sabukazan@gmail.com

\section{INSTAGRAM ÖRNEĞİ ÜZERINDEN SOSYAL MEDYADA HİKÂYE ANLATICILIĞI}

\section{$\ddot{O} \mathbf{z}$}

Sosyal ağ sitelerinin fotoğraf, video, yazı ve içerik paylaşımı gibi özellikleri taşıyor olması bu sitelerin yaygın kullanımına zemin hazırlamıștır. Bugün Instagram, Snapchat, Facebook gibi uygulamalar popüler sosyal ağ sitelerinin ilk sıralarında yer almaktadır. Bu uygulamalarda bulunan hikâye özelliği ile 24 saatlik zaman diliminde benlik sunumları yapılmaktadır. Çalışmada, bireylerin Instagram' da benliklerini nasıl inşa ettiği ve benlik sunumlarını nasıl gerçekleștirdiği araștırılmıștır. $\mathrm{Bu}$ çerçevede Goffman'ın Yayılan İzlenim Kuramı çalışmanın temelini oluşturmaktadır. Goffman'a göre birey performansını sunarken kendisini izleyenlerin beğenisi kazanmaya yönelik performansını idealize eder. Instagram' da bireyler kendilerini nasıl göstermek, sunmak istiyorsa o yönde hikâye paylaşmaktadır. Dolayısıyla çalışmada incelenen profillerin, bize sosyal medyada benlik oluşturma ve benlik sunma konularında hangi araçların kullanıldığı araştırılmaktadır.

Çalışma kapsamında sosyal medyada paylaşılan tüm hikâyeleri incelemek olanaksızdır. Bununla birlikte analizi yapılacak hikâyeler için Türkiye'de sınırları içinde yașadığı düșünülen ve Instagram sosyal medya uygulamasında aktif "hikâye" paylaşımı yapan gruplar dâhil edilmektedir. Bu gruplar; yeni anneler, yeni evliler, çok gezenler, gösterişçiler, zenginler, alışverişkolikler, mutlu insanlar, yemekçiler ve çocuklu anneler kategorilerinden oluşmaktadır. Çalışmada 30 Nisan - 10 Mayıs 2017 tarihleri arasında hikâye paylaşımı yapan 18 profil analiz edilmektedir. Çalışmanın kuramı ve yöntemi, Instagram sosyal ağ sitesinin yapısı açılanmak, insanların bu ortamı hangi koşullarda kullandığını öğrenmek, hikâye oluștururken kullanılan araçları incelemek ve benliğin sunumunda görsellerin neyi ifade ettiğini açıklamak doğrultusunda çalışmaya 1şık tutacaktır.

Anahtar Kelimeler: Sosyal Medya, Sosyal Medyada Benlik Sunumu, Hikâye Anlatımı, Yayılan İzlenim, Instagram, Dijital Öyküleme.

\section{STORYTELLING IN SOCIAL MEDIA THROUGH THE EXAMPLE OF INSTAGRAM}

\section{Abstract}

The features of social network sites, such as photo, video, text and content sharing that have laid the groundwork for the widespread use of these sites. Today, applications such as Instagram, Snapchat, and Facebook are the most popular social networking sites. Selfpresentation is made in 24 hour time zone with the feature of story in these applications. How individuals construct their selves and how they realize their self-presentation are researched in the study. In this framework, Goffman's Radical Impression Theory is the basis of his work. According to Goffman, while individual represent his or her performance, he or she idealiazes performance in order to gain likes of followers. The individuals share the story in the way of that they show or present themselves in Instagram. Therefore, which tools are used in the social media's self-presentation and the formation of self are investigated.

The study includes the groups that are thought to live within the boundaries of Turkey and share active "story" in Instagram social media practice. These groups are new mothers, new wives, multi-viewers, protesters, wealthy people, shopcholiks, happy people, dishonest and mothers of children. 18 profiles that share stories between 30 April and 10 May 2017 are analyzed in the study. The theory and methodology of the work will sort out to explain the structure of the Instagram social network, to find out in how circumstances people use it, to investigate the tools which are used to create the story, and to describe what the images mean in the presentation of the self.

Keywords: Social Media, Self-Presentation in Social Media, Storytelling, Expansive Impression, Instagram, Digital Narration. 


\section{Giriş}

İnsanlık, tarih boyunca pek çok köklü yeniliklere tanık olmuştur. Dünyayı dönüştüren ve Mc Luhan'ın deyimiyle küresel köy haline getiren değişikliklerin altında bilim ve teknoloji yer almıştır (Erdoğan, Alemdar, 2010,145). 19. Yüzyıldan bu yana sürekli değişim ve gelişim içerisinde olan, iletişim biçimleri de zamanla evirilmiş ve yepyeni bir boyut kazanmıştır. Geleneksel medya içinde sayılan radyo, televizyon ve gazeteler popülerliğini internete bırakmıştır. İnternet teknolojisi bugün dünyanın her yerine uzanabilmektedir. İnternetin yakınsama fonksiyonuna sahip bir mecra oluşu, farklı kitle iletişim araçlarının bir araya gelmesine olanak tanımıştır (Kırık, 2013, 71).

Sosyal ağlar ayrıca kimlik üretimine olanak sağlayarak; bireylerin benliklerini sundukları ve sergiledikleri bir 'mekân' olma işlevi görmektedir (Güzel, 2016, 83). Mobil teknolojilerinin gelişimiyle zaman ve mekân uzamlarını ortadan kaldıran sosyal medya kullanımı, kullanıcılara 7/24 etkileşim sağlayarak, popüler bir hale gelmiştir. Mobil teknolojilerin sosyal medyaya bağlanabilmesi ve fotoğraf çekme özelliğinin olması, fotoğraf çekme eyleminin 'sanal ortama' kaymasına neden olmuştur (Özdemir, 2015, 119). Bu durum, internet kullanıcılarının, imajlarını sosyal medya üzerinden paylaşabilmesine ortam hazırlamıştır. Böylelikle birey günlük hayatının önemli bulduğu kesitlerini, sanal ortamda sergileyebilmektedir. Tüm bu olanaklar gün geçtikçe sosyal ağların daha popüler bir hal almasını sağlamakta ve sanal dünyayı herkes için erişilebilir kılmaktadır.

İletişimde yeni teknolojilerin ortaya çıkmasıyla birlikte hikâye anlatımı, radyo, televizyon gibi geleneksel iletişim araçlarından internet ortamına taşınmıştır. İnternetin çift yönlü yapısı sayesinde, hikâyelerin tek yönlü doğası yeni bir boyut kazanmış ve yerini etkileşimli hikâyelere bırakmıştır. Bugün, televizyon karşısında edilgen bir rolde olan izleyici, sosyal medya araçlarıyla birlikte etkin hale gelmekte ve internet ortamında hikâyelerini aktarabilmektedir (Akbayır, 2016, 68). Sosyal medya uygulamalarına eklenen hikâye özelliği bireyin 24 saatlik zaman içerisinde paylaştığı fotoğraf ve 10 saniyelik kısa videoları paylaşabilmesine olanak tanımaktadır.

Snapchat ile başlayan hikâye anlatıcılığı diğer bir değişle 'snap atma' zamanla popüler bir hale gelmiş ve diğer yaygın uygulamalara (Instagram, Facebook Messenger, WhatsApp) da eklenmiştir. Özellikle Instagram'ın çok hızlı büyüyen bir yapısının olması, uygulamanın her geçen gün iyileştirilmesi ve güncelleştirilmesini sağlamıştır. Instagram'ın popüler bir sosyal medya uygulaması olması çalışmanın konusu açısından önem taşımaktadır. Instagram yap1 itibariyle fotoğraf ve video paylaşımına izin veren, anlık mesajlaşma olanağ 1 bulunan, yorum yapabilme ve beğenme özellikli bir uygulamadır. Instagram'da hikâye, ana sayfada pembe yuvarlak bir çerçeve içinde gösterilmektedir. Takip edilen kullanıcıların hikâyelerini görüntülemek için bu yuvarlağa dokunmak gerekir. Ayrıca kullanıcının kendi profil sayfasından da hikâyesine ulaşmak mümkündür. Hikâye paylaşımında uygulamanın sunduğu bir takım renk efektleri, duygu ikonları ve tipografik şekiller bulunmaktadır.

Çalışmada Web 2.0 teknolojilerinden olan Instagram uygulamasındaki hikâye anlatıcılı̆̆ 1 ve bireyin hikâye anlatırken nasıl bir benlik sunumu sergilediği araştırılmaktadır.

\section{Küreselleșme ve Teknolojik İlerleme}

Yirminci yüzyılın son on yılından beri, teknolojik yeniliklerle birlikte küresel yapılanmanın en önemli süreci vuku bulmaktadır (Talas, Bildirici, 2008, 10). Nasıl 18. ve 19.yüzyılda yaşanan sanayi devrimi kendinden önceki siyasal yapıların çoğunu yıkmış veya gereksiz hale getirmişse, bugün bilgi ve enformasyon devrimi de aynı etkileri yaratmaktadır (Yılmaz, 2004, 59).

Toplumsal değişimi sağlayan en önemli alt yapı unsurlarından biri internettir. İnternet toplumsalı kuran ve toplumu değiştiren bir olgudur. İnternetin gelişimi, kullanımı ve yaygınlaşması insan ve dünya üzerinde bir takım olumlu ve olumsuz etkiler yaratmış, sonuç olarak etkin bir teknoloji haline gelmiştir (Dedeoğlu, 2016, 28). İnternetin yaygın kullanımıyla birlikte Web 1.0, Web 2.0 ve Web 3.0 teknolojileri ortaya çıkmış, bu teknolojiler kullanıcı ve 
etkileşim ilişkisine göre sınıflandırılmıştır. Web 1.0'ın temelinde kişisel eğlenme yaklaşımı yer almaktadır. Web 2.0 teknolojisinin ortaya çıkmasıyla birlikte bu yaklaşım, kişisel yayıncılığa dönüşmüştür. Ancak kişisel yayıncılığ 1 gerçekleştirebilmek için bazı program ve kodlamaları bilmek gerekmektedir. Web 3.0 temeliyle hazırlanan uygulamalar, bu bilgilere duyulan ihtiyacı ortadan kaldırmaktadır. Web ortamındaki karmaşıklık Web 3.0 teknolojisiyle yerini görsel tabanlı sistemlere bırakmaktadır. "Tutma, sürükleme ve yerine bırakma" yaklaşımına dayanan bu sistem, kullanıcının içeriğe müdahalesine olanak tanımaktadır. Bu teknolojide elde edilen veriler, hem kullanıcılar tarafından kullanılabilmekte hem de bilgisayar sistemlerinde karşıllk bulabilmektedir (Yengin, 2015, 49-50). Bu özelliği ile Web 3.0 toplayıp birleştirme devri olarak tanımlanmaktadır.

İnternetin doğasında var olan hız, düşük maliyet, etkileşim, kolay erişilebilirlik gibi avantajlarının yanı sıra multimedya özelliklerinin kullanılmasıyla ortaya çıkan rekabetçi üstünlük, yeni medya ve iletişim teknolojilerini, kitle iletişim araçları dediğimiz eski/geleneksel medya karşısında önemli bir güç haline gelmiştir. İnternet ve iletişim teknolojilerinin gelişmesiyle ortaya çıkan yenidünya düzeni, toplumun pek çok alanında olduğu gibi medya alanında da büyük değişiklikler meydana getirmiştir (Bulunmaz, 2011, 26).

Klasik kitle iletişim araçlarının oluşturduğu ve eski medya olarak tanımladığımız medya, günümüzde yerini yeni medya teknolojilerinin olduğu bir düzeni yaratmıştır. Yeni medya farklı iletişim boyutlarının aynı anda gerçekleşmesine olanak tanımaktadır. Yeni medyada iletişim geleneksel medyadan farklı olarak; tekilden çoğula ya da çoğuldan çoğula eş zamanlı sohbet hizmeti şeklinde gerçekleşmektedir (Binark, 2007, 23).

\section{Hikâye Anlatma Aracı Olarak Sosyal Medya}

Bilgisayar teknolojisinin, hızlı gelişmesi ve internetin günlük hayatın içinde yer bulmasıyla bu iki teknoloji toplumun vazgeçilmezi haline gelmiştir. Evde, iş yerinde, okulda, parkta daha pek çok yerde bilgisayar teknolojileri ve bunun uzantısı olan internet kullanılmaktadır. İnternet, birden fazla bilgisayar sisteminin birbirine bağlı olduğu ve dünyada sürekli gelişim, değişim, güncelleme gösteren bir iletişim ağı olarak tanımlanmaktadır (Çalık, Çınar, 2009, 84).

Bugün bilgisayar ve telekomünikasyon ağları dünyayı saran yeni ve yapay bir küresel ağ oluşturmuştur. Radyo linkleri, uydu bağlantıları ve kablo şebekelerinin oluşturduğu bu yapay atmosfer, dünyayı çerçeveleyen bir doku gibi bir yerden başka bir yere sürekli sesli, görüntülü ve yazılı bilgi aktarmaktadır. Bilgisayarların donanım niteliklerinin gelişmesiyle birlikte daha hızlı işlem yapan işletim ve yazılım sistemleri gelişmiştir. Bu yeniliklere eklenen ağ teknolojilerindeki gelişmeler sayesinde çok fazla verilerin işlenebilmesi olanaklı hale gelmiştir. İnternetin tüm bu gelişmeler içerisinde ayrıcalıklı bir etkisi olduğu söylenebilir (Dedeoğlu, 2016, 15). İnternet, hayatımızın he noktasına bilgi gönderme ve eriştirme işleviyle bir iletişim devrimi gerçekleştirmiştir. Bu devrimle birlikte veri analizi ve değişimini kolaylaşmış, küresel iş döngüsü hızlanmıştır (Vural, Bat, 2010, 3351).

İnternet ayrıca kişiler arasındaki mesafe, yaş, ırk, kültür gibi özellikleri ortadan kaldırmaktadır. İnternetin anonim yapısı sayesinde aynı düşüncedeki insanlar, zaman ve mekândan bağımsız kolaylıkla bir araya gelebilmekte, sanal gruplar oluşturabilmekte, farklı kültürden birey ve grupları tanıyabilmekte, her türlü düşünceyi daha özgür ifade edebilmektedir (Sarıfakıoğlu, 2007, 54). Mc Luhan'ın 1960'larda kitle iletişim araçlarının gelişimi ile dünyanın küresel köye dönüştüğünü, böylece dünyanın küçülüp birbirine bağlandığını savunmuştur. Ona göre dünyanın her yerini mesaj ve görüntüler sarmıştır. Köylerde nasıl insanlar birbirinden haberdar oluyor ve birbirini tanıyorsa bugün internet aracılığıyla da dünyanın her yerinden haberdar olmak mümkün hale gelmiştir (Yaylagül, 2014, 70). İnternetin yakınsama fonksiyonuna sahip bir mecra oluşu, farklı kitle iletişim araçlarının bir araya gelmesine olanak tanımıştır (Kırık, 2013, 71). Böylelikle farklı toplum ve yaşam koşullarında yaşayan insanlar internetin sunmuş olduğu sosyal paylaşım ağlarında bir araya gelebilmekte ve karş1lıklı görüş alışverişinde bulunabilmektedir.

www.ercines-akademia.com 
İnternetin sunduğu bir diğer olanak ise sosyal ağlar ve sanal topluluklardır (İspir, 2013, 11, 12). İnternet teknolojisinin kitle iletişim araçlarıyla uyumlu çalışmasıyla birlikte yeni medya teknolojileri oluşmuş, bu teknolojiler bireysel ve toplu paylaşıma imkân veren sosyal paylaşım sitelerinin ön plana çıkmasını sağlamıştır. Sosyal ağlar iletinin anlık paylaşılmasına olanak vermektedir. Ayrıca geri bildirim de bir o kadar hızlı sağlanmaktadır. Kullanıcılar sanal oyunlara, televizyon program ve haberlerine, çevrimiçi sitelere aktif katılabilmektedir. Ayrıca çevrimiçi gruplar sayesinde kullanıcıları bir arada tutmak, çevrimiçi tartışma başlatmak ve bu tartışmanın dünya genelinde yayılmasını sağlamak mümkün olabilmektedir (Kırık, 2013, 75 76). İnternet, yapısı ve dili sayesinde, insanları kültürel bir biçim ve kimliğe davet etme gücüne sahiptir. İnternet ve sosyal ağlar insanlara, moda eğlence, kadın/erkek kimliği gibi kategorilerle seslenmektedir. Bu çağrıya cevap veren kullanıcı bir süre sonra, farklı kimlik ve kültürel kodlarla bütünleşmektedir. Dolayısıyla iletişim teknolojileri, kuşaklar arası farklılıkları artırmaktadır.

Teknolojinin dönüştürdüğü diğer bir alan ise hikâye anlatımıdır. Günlük hayatın önemli bir unsuru olan hikâyeler, teknolojinin gelişimiyle birlikte sosyal medyaya taşınmıştır. Buradaki dijital hikâye anlatma, dijital biçime dönüştürülmüş hikâyelerden oluşmaktadır. Dijital hikâye anlatma, ‘etkileşimin’ olduğu bir ortamda ses, grafik, resim, müzik, görüntü, eğlence ve metne dayalı anlatımların sunulma süreci olarak ifade edilmektedir (Turgut, Kışla, 2015, 102-103). Dijital öykü anlatımı, teknolojiyle var olmaktadır. Dijital öykü anlatımı, bilgisayar kullanıcıların kendi konularını hikâyeleştirmesine, bir hikâye anlatıcısı olmasına imkân tanımaktadır (Küngerü, 2016, 35). Bu hikâyeler, çeşitli multimedya uygulamalarıyla gerçekleştirilebilmektedir. Web 1.0'dan Web 2.0'ye geçilmesiyle birlikte, insanların ürettikleri öyküler daha erişilebilir ve daha görülür olmuştur. Web 2.0 teknolojisi içinde yer alan sosyal medya uygulamalarında insanlar günlük olarak hikâye paylaşabilmekte ve hikâyelerini süsleyebilmektedir. Böylelikle etkileşimin yoğun olduğu çevrimiçi sosyal ağlarda birey, kimliğini dilediği şekilde inşa edebilmektedir.

Eski çağlarda ilk insanlar nasıl hikâyelerini resmetmek için mağara duvarı gibi araçlara ihtiyaç duyuyorsa; dijital hikâye anlatımında da bir takım araçlara ihtiyaç duyulmaktadır. Dijital hikâye anlatımının ruhu, görseller aracılı̆̆ıyla anlatılmaktadır. Bu görseller fotoğraf, video ve infografiklerden meydana gelmektedir. Hikâye anlatımı ayrıca bir filmdeki dekor, kostümler ve kamera hareketleri olabildiği gibi, görsel efektler, ses ve animasyon da olabilmektedir (Bilici, 2016, 33). Dijital hikâye anlatımı montaj/kurgu programları, düşük bütçeli kamera ve dizüstü bilgisayarlarla kısa hikâyelerin oluşturulmasını sağlamaktadır. Bu hikâyeler öznel/kişisel hikâyelerdir, internet ortamında yayınlanmak üzere yapılmaktadır.

Dijital hikâyeler geleneksel yayın materyallerine benzememektedir. Örneğin filmlerden farklıdır fakat resimlerden meydana gelmektedir. Diğer bir taraftan ses kullanımı vardır fakat üretim değeri stüdyodan daha çok resim albümü gibidir. Dolayısıyla televizyona da benzememektedir (Küngerü, 2016, 36-37). Dijital öykü kullanıcıları kendi kişisel albümlerinden faydalanarak diledikleri yerde hikâye oluşturabilmektedir. Fotoğraflar da hikâyelerin anlatılmasında, geniş kitlelere yayılmasında, sosyal ağlarda etkileşim oluşmasında ve satış artırmada önemli bir yere sahiptir (Soydaş, Yılmaz, 2016, 1114). Çok fazla yazılı içerik yerine az sayıda görsel kullanımı akılda kalıcılık bağlamında oldukça etkilidir. Fotoğraflardan her biri gerçek bir nesneden esinlenerek kendi özel gerçekliğini anlatır. Fotoğraf yorumlanırken gerçek nesne ile fotoğraftaki nesne arasındaki ilişki ortaya konur. Fotoğrafın anlamı, kişinin bakış açısı ve gösterilen nesne ile ifade edilir. Fotoğraf görüntüsü, gerçek nesneyi yansitan fotoğraftır. Bu anlamda gösterge ve nesne arasında benzerlik ilişkisi bulunur (Günay, 2008, 11). Dolayısıyla bir yansitma durumu söz konusudur.

Düşüncenin varlığı, paylaşım ve gelişimi göstergeler ile mümkün olmaktadır (Günay, 2008, 2). Lotman'a göre göstergeler; gözün gördüğü ve görünenin arkasındaki gerçeği anlama ve yorumlama temeline dayanan bir anlamlandırma biçimidir. Göstergeler insanlık tarihinden itibaren farklı algılanmış ve anlamlandırılmıştır. Böylelikle anlamı üreten toplumlar içerisinde, gündelik hayatı kolaylaştırmış ve diğer insanlarla iletişim kurulmasına olanak sağlayan araçlar 
haline gelmiştir (Lotman, 2012, 13). Lotman'a göre göstergeler, toplumlardaki bilgi değiş tokuşu sırasında; nesne ve kavramların fiziksel anlatımıdır.

Göstergebilim alanında önde gelen en önemli isimlerden biri ise dilbilimci Roland Barthes'tır. Barthes, çalışmalarında genel olarak anlam ve anlamlandırma kavramları üzerinde durmuştur. Ona göre bu dizgeler dil ile gerçeklik kazanmaktadır. Dolayısıyla dil her yerdedir. Barthes görüntü, jest ve mimiklerin anlamlı imgeler oluşturduğunu, dil'in gücünü yazı'nın ifade ediliş biçiminden aldığını belirtir. Barthes Göstergebilim İlkeleri kitabında göstergebilimi sinıflandırarak, Dil ve Söz, Gösteren ve Gösterilen, Dizim ve Dizge, Düz anlam ve Yan anlam olarak açıklamıştır (Sivas, 2012, 532). Barthes'a göre göstergenin temsil ettiği kavram düz anlam; göstergenin temsil edilme şekli ise yan anlamdır. Ona göre göstergeler, toplum içinde kültürel olarak yer edinmiş anlamlara ya da yan anlamlara gönderme yapmaktadır. Örneğin fotoğrafın düz anlamı, çekilen; yan anlamı nasıl çekildiğidir (Bircan, 2015, 20). Yan anlamların oluşması için, toplumun hafızasına yerleşmiş ipuçlarına ihtiyaç vardır. Barthes'a göre gösterge bir gösteren ve bir gösterilen üzerine kuruludur. Gösterenler düzlemi anlatım düzlemini, gösterilenler düzlemiyse içerik düzlemini oluşturur. (Barthes, 2014, 47-48). Bireysel alanlarda ise ipuçlarını, metin ya da ortam verir. Örneğin bir yerde kullanılmayan trafik işareti buldunuz. Bu işaretlerin yoruma açık yan anlamları bulunmaz. Ancak siz trafik levhasını evinizin bir köşesine asarsanız, onu bulunduğu ortamın dışına çıkarmış ve başka bir bağlama sokmuş olursunuz. Böylelikle trafik ışığı düz anlam katında bir gösterge olmaktan çıkar. Eviniz hakkında bilgi veren bir nesne haline gelir (Akerson, 2005, 127-128). Trafik levhasını koyduğunuz yer ise, levhanın yeniden anlamlandırılmasını sağlar.

Bugün, kültürlerin oluşumunda ve başka kültürlerin etkilenmesinde görüntülerin önemli bir yeri bulunmaktadır. Dijital görsel kültür, dijital görüntülerle kültürleri görünür hale getirmenin yanı sıra kültürleri değiştirici yönüyle incelenmelidir (Güney, 2014, 76-77). Çünkü yeni medya teknolojilerinin, iletişimi kolaylaştırdığı düşünüldüğünde; insanlar tarafından üretilen imgelerin, insanların biçimlenmesinde önemli rol oynadığı söylenebilir.

İmgelerin biçimlendirdiği bir diğer alan ise sosyal medyadır. Çevrimiçi yani sanal ortamın, fiziksel boyutu bulunmamaktadır. Bu durum duyguların sanal ortamlarda ifade edilişini zorlaştırmaktadır. İnsanların sanal ortamlarda duygu ve düşüncelerini ifade edebilme ihtiyacı, özellikle Z kuşağının kısa yoldan iletişim kurma isteği bir takım duygu ikonlarının ortaya çıkmasına zemin hazırlamıştır. Dijital iletişimin önemli bir parçası haline gelen bu görseller ile internet kullanıcıları, sözcüklere ihtiyaç duymadan yalın ifadelerle duygu ve düşüncelerini, karşı tarafa kolaylıkla iletebilir hale gelmiştir (Kurtoğlu, Özbölük, 2016, 147). Karmaşık ve ifade edilmesi güç mesajların tek bir duygu ikonuyla anlatılabilmesi, internet kullanıcıların mesajlarında daha yoğun duygu aktarımına olanak sağlamaktadır.

Duyguların ifade edilmesi, metnin mizah yönünün artırılması, mesajın güçlenmesi açısından duygu ikonlarının iletişim fonksiyonlarını çevrimiçi alana taşıdığı belirtilmektedir (Kurtoğlu, Özbölük, 2016, 147-148). Yüz yüze iletişimde his, duygu, düşünce, eylem gibi fonksiyonlar durum hakkında bilgi verirken; çevrimiçi iletişimde bu bilgiler duygu ikonları aracılığıyla iletilmekte ve paylaşılmaktadır. Bireyler duygularını ifade ederken duygu ikonu kullanmakta; yüz yüze iletişimde sözlü olarak ifade edilebilecek duyguların yerini duygu ikonları almaktadır (Gökaliler, Saatcıŏglu, 2016, 70). Bir iletişim ortamı olan sosyal medyada eylemin açıklanması da yine duygu ikonları kullanılarak sağlanmaktadır.

Birçok anlatı kuramcısı anlatıcı ile ilgili çeşitli görüşler ortaya koymuştur. Bu görüşler ışı̆̆ında ise çeşitli tipolojiler geliştirmiştir. Ancak birbirinden farklı özellikte olan bu tipolojilerin kullanışlılığı tartışma konusu olmuştur. Tipolojilere eleştirel yaklaşan Schmid'e göre araştırmacılar anlatıcı ve perspektif tiplerini birbirine karıştırmakta, asıl konuyu görememektedir. Ona göre anlatıcı tipleri belirlenmeden önce anlatıcı kavramı açıklanmalı ve çerçevesi çizilmelidir. Schmid anlatıcı ve perspektif tiplerindeki karışıklığı engellemek için basit bir anlatıcı tipolojisi önermektedir (Dervişcemaloğlu, 2014, 124-125); 


\begin{tabular}{|l|l|}
\hline ÖLÇÜT & ANLATICI TIPLERI \\
\hline Sunuş Tipi & Açık - Kapalı \\
\hline Diegetik Durum & Diegetik - Diegetik Olmayan \\
\hline Hiyerarşi & Birincil - İkincil - Üçüncül \\
\hline Belirginlik Derecesi & Fazlasıyla Belirgin - Çok Az Belirgin \\
\hline Şahsilik & Şahsi - Gayrişahsi \\
\hline Göstergelerin Homojenliği & Yoğun - Dağınık \\
\hline Değerlendirmeci Konum & Nesnel - Öznel \\
\hline Yetkinlik & Her Şeyi Bilen - Sınırlı Yetkiye Sahip \\
\hline Mekânsal Konum & Her Yerde Olabilen - Belirli Bir Yerde Sabit Duran \\
\hline Karakterlerin Bilincine Nüfuz Etme & ifade Edilmiş - Ifade Edilmemiş \\
\hline Güvenilirlik & Güvenilmez - Güvenilir \\
\hline
\end{tabular}

Schmid'in tablosu her ne kadar açık görünse de bazı kavramlara değinmek faydalı olacaktır. Hiyerarşi ölçütünün karşısına denk gelen birincil-ikincil-üçüncül anlatıcı tiplerinde, anlatıcı, bir anlatının "anlatıcısı" olarak görevlendirildiğinde geçerli olur. Schmid'e göre (Dervişcemaloğlu, 2014, 126) birincil anlatıcı, çerçeve hikâyenin anlatıcısı; ikincil anlatıcı, iç veya alt hikâyenin anlatıcısı; üçüncül anlatıcı ise birincil alt hikâyenin hem karakteri hem anlatıcısıdır. Binbir Gece Masalları'nda ikincil anlatıcı konumunda olan Şehrazat'ın, birincil anlatıcıdan daha fazla ilgi görmesi bunun en güzel örneğidir. Schmid'in bir diğer ayrımı ise diegetik ve diegetik olmayan ayrımıdır. Ona göre eğer anlatıcı hikâyede karakter olup, kendisi ile ilgili bir şeyler anlatıyorsa diegetik bir anlatıcıdır. Bu anlatıcı hem exegesis yani anlatan hem anlatan hem de anlatılan öykü yani diegesis düzeyde karşımıza çıkabilir. Diğer bir yandan diegetik olmayan anlatıcı, kendisi ile ilgili bir şeyler anlatmaz; başkaları ile ilgili şeyler anlatır $(2014,127)$.

\section{Aktif Hikâye Paylaşan Profillerin Kategorilendirilmesi}

Bireyler sanal ortamdaki ilişkilerini sürdürürken bir takım sunumlar gerçekleştirirler. $\mathrm{Bu}$ çerçevede bireyler sosyal etkileşim sağlarken, gerçekte olduklarından farklı bir şekilde davranış sergileyebilirler. Role uygun davranan bireyler, başka bir internet kullanıcısının gözünde belli kimlikler oluşturma ihtiyacı hisseder. Web 2.0 teknolojisinin gündelik hayatta aktif kullanımıyla birlikte, bireyler sosyal etkileşimlerini bu alanlarda gerçekleştirmeye başlamıştır(Biçer, 2014, 67). Bu kuram Instagram uygulaması üzerinde son derece önemli veriler elde etmemizi sağlamaktadır. Goffman'ın kuramıyla benlik sunumundaki çeşitlilikler daha net açıklanabilmektedir. Instagram kullanıcıları hikâyelerinde, başka bir kullanıcının zihninde nasıl yer etmek istiyorsa o şekilde performanslarını paylaşmaktadır ( Soncu, 2016, 229). Goffman'a göre $(2014,17)$ hayat bir tiyatro sahnesidir ve kişiler aktördür. Aktörler, seyircinin kendisi hakkında olumlu düşünmesini ve olumlu izlenimler taşımasını ister. Seyirciden almak istediği tepkiye göre çeşitli eylemlerde bulunur. Goffman'a göre benliğin sunumu iki şekilde gerçekleşir; verilen izlenim ve yayılan izlenim. Verilen izlenim sözlü simgeleri içerirken, yayılan izlenim gözlemcilerin kişi hakkında bilgi edinmelerini sağlayacak eylemleri kapsar. Buradaki eylemlerle, eylem sirasında iletilen bilgiler ifade edilmektedir $(2014,18-20)$. Goffman kuraminda hikâye ve toplum arasındaki etkileşimi şu şekilde ifade etmektedir;

Etkileşim: Fiziksel olarak aynı ortamda bulunan bireylerin karşı1ıklı eylemleri ve bu eylemlerin birbirleri üzerindeki etkileri olarak ifade edilebilir.

Performans: Kişinin herhangi bir gözlemci kümesi karşısında, onları etkileyebilmek için sergilediği tüm eylemler olarak tanımlanabilir. 
Rol - Rutin: Bir performans sırasında önceden belirlenmiş olan ve başka bir durumda da sergilenebilecek olan eylem kalıbıdır.

Aktör - Oyuncu: Performansı sunan, sergileyen kişi.

Gözlemci: Performansı izleyen ve performans hakkında izlenim edinen kişi.

Seyirci: Aktörün paylaştığı performanstan etkilenen kişi.

Verilen İzlenim: Performansın aktör tarafindan sözlü simgelerle ifade edilmesi.

Yayılan İzlenim: Gözlemcinin, aktör hakkında bulgu edinmesini sağlayacak sözsüz eylemleri içerir. Jest, mimik, duruş, bakış vs.

Set: Önünde, içinde veya üzerinde insan faaliyetlerine ortam sunan, mobilya, dekor ve arka plan düzenlemeleridir.

Kişisel Vitrin: Cinsiyet, yaş, ırksal özellikler, boy, konuşma kalıpları, jest ve mimiklerdir (Goffman, 2014, 16-35).

Ayrıca hikâye paylaşımlarında, Goffman'ın kuramsal temelini oluşturan parametreler değerlendirerek, bireylerin kendilerini nasıl sunduklarına bakılacaktır. Bu parametreler; Dramatik Canlandırma, İdealize Etme, İfade Denetiminin Elde Tutulması, Yanlış Sunum, Gizemlileştirme, Gerçeklik Ve Düzmece, Takımlar, Bölgesel Davranışlardır.

1) Dramatik Canlandırma: Kişi başka insanların karşısında, eylemlerini bazı doğrulayıcı olguların dramatik olarak belirtecek işaretlerle donatır. Çünkü söz konusu eylemlerinin, başkaları açısından anlam taşıması için, oyuncu bunları etkileşim sırasında iletmek istediklerini ifade edebilecek şekilde sergilemelidir (Goffman, 2014, 40-41).

2) İdealize Etme: Kişinin kendini başkalarına sunduğu performans, toplumun değer ve davranışlarını temsil eder. Eğer kişi performansını ideal standartlara uygun olarak ortaya koymak istiyorsa, bu standartlara ters düşen eylemleri gizlemek zorunda kalacaktır (Goffman, 2014, 45-57).

3) İfade Denetimi: Performans sırasında uyumsuz davranışlar, toplumsal değerlere aykırı hareketler (geğirme, esneme, yellenme gibi.), setin düzgün hazırlanmaması ve etkileşime ilgisiz olma, bunlar oyuncunun performanslarında ifade denetimi olmadığını ortaya koyar. $\mathrm{Bu}$ durumlardan bir ya da birkaçının meydana gelmesi seyircinin role olan inancını zedeler ( Goffman, 2014, 59-60).

4) Yanlış Sunum: Oyuncunun performans ipuçlarını yanlış kullanımı performansın inandırıcılığını ortadan kaldırır (Goffman, 2014, 65-68).

5) Gizemlileştirme: Performansın bazı konularını ön plana çıkarırken bazılarını gizleme (Goffman, 2014,73).

6) Gerçeklik ve Düzmece: Gerçeklik, gerçek olduğuna içtenlikle inanılan. Düzmece sahte ve hata payı yüksek olan (Goffman, 2014,76).

A) Takımlar: Performansların esas amacı oyuncunun değil sahnelenen görevin özelliklerini ifade etmektir. Bu bağlamda performans ne tür bir bilgi iletiyor olursa olsun, önemli olan olumlu tutum bırakmaktır. Takımlar, performansın birden fazla kişi ile sergilenmesidir (Goffman, 2014, 82).

B) Bölgesel Davranışlar: Performansın yarattı̆̆ izlenim açısından yer ve zaman uygun olmalidır (Goffman, 2014, 107).

Çalışma kapsamında sosyal medyada paylaşılan tüm hikâyeleri incelemek olanaksızdır. Bununla birlikte analizi yapılacak hikâyeler için Türkiye'de sınırları içinde yaşadığı düşünülen ve Instagram sosyal medya uygulamasında aktif 'hikâye' paylaşımı yapan gruplar dâhil edilmiştir. İncelenen 100 aktif Instagram profilinden 18'i gruplandırılmıştır. Bu gruplar şu şekilde kategorize edilmiştir; yeni anneler, yeni evliler, çok gezenler, gösterişçiler, zenginler, 
alışverişkolikler, mutlu insanlar, yemekçiler ve çocuklu anneler oluşturmaktadır.

Bütün gruplar en az 2 kişiden oluşmaktadır. Bu kişilerin görselleri ve ismi mahremiyete gösterilen özen sebebi ile saklı tutulmaktadır.

Çalışmada İncelenen Gruplar

\begin{tabular}{|c|c|}
\hline Yeni Anneler & $\begin{array}{l}\text { B.T. } \\
\text { N.B.Y }\end{array}$ \\
\hline Yeni Evlilier & $\begin{array}{l}\text { S.S. } \\
\text { E.A. }\end{array}$ \\
\hline Çok Gezenler & $\begin{array}{l}\text { R.B. } \\
\text { F.K. } \\
\text { D.O. }\end{array}$ \\
\hline Alışveriş Kolikler & $\begin{array}{l}\text { O. } \\
\text { B. }\end{array}$ \\
\hline Gösterişçiler & $\begin{array}{l}\text { S.. S. } \\
\text { E.A. } \\
\text { i.E. } \\
\text { N.B. }\end{array}$ \\
\hline Kendini Gösterenler & $\begin{array}{l}\text { N.A. } \\
\text { H.S. } \\
\text { T.R. }\end{array}$ \\
\hline Zenginler & $\begin{array}{l}\text { K.D. } \\
\text { C.Ç. }\end{array}$ \\
\hline
\end{tabular}

Bu grupların örneklem alınmasındaki etkenlerden en önemlisi aktif internet kullanıcısı olmaları ve en az 10 bin takipçi sayısına sahip olmalarıdır. Hikâye özelliğini kullanan grupların gün içerisinde birden çok hikâye paylaşımı yapması ve hikâye paylaşırken duygu ikonu, text, ikonografi gibi araçları kullanıyor olması beklenmektedir. Hikâyeler 10 günlük zaman takibinde incelenecek, kişi ya da grupların benlik sunumları ve ifade şekilleri açıklanacaktır. Hikâye özelliğinin aktif kullanımı araştırma probleminin çok yönlü anlaşılmasını sağlayabilir ve araştırmaya veri açısından zenginlik katabilir. Araştırmanın öncelikli amacı Instagram uygulamasında çok fazla süre geçiren ve bu ortamda yoğun paylaşımlarda bulunan kişiler olduğu için katılımcılar için 3 kriter belirlenmiştir;

- Katılımcıların en az 100 görsel paylaşmış olması

- Hikâye özelliğini mutlaka kullanıyor olması

- Günde en az 2 hikâye paylaşıyor olması

Bütün gruplar ortak özellikler saptayabilme açısından en az 2 kişiden oluşmaktadır. $\mathrm{Bu}$ kişilerin görselleri ve ismi mahremiyete gösterilen özen sebebi ile saklı tutulmuştur. Çalışma incelenen grupların, 30 Nisan - 10 Mayıs 2017 tarihleri arasında paylaştıkları hikâyeler incelenmiştir. Araştırma sırasında her gruptan takip edilen bireylerin paylaştıkları hikâyeler göstergebilimsel olarak analiz edilmiştir. 
Çalışmada incelenen hikâyelerin sahibine Goffman'ın kuramından hareketle aktör adı verilmiştir. Kişinin belirli bir seyirci kümesini etkileyebilmek için sergilediği tüm eylemlere performans adı verilmektedir. Burada kişilerin etkilemek istedikleri bireyler, seyirci olarak adlandırılmaktadır. Instagram hikâyelerinin Goffman'ın ifadesiyle, yayılan izlenim olduğu varsayılmaktadır. Seyircilerin, aktör hakkında bulgu edinmesini sağlayacak, jest, mimik, duruş gibi sözsüz eylemlerine yayılan izlenim denilmektedir. Bunlar görsel simgelerdir. Goffman'ın tüm bu kuramsal çerçevesi ile Instagram hikâyelerinde bireylerin benlik inşaları ve diğer kullanıcilara sunumları saptanabilir.

\section{Instagram Hesaplarında Benlik Sunumlarının İncelenmesi}

\section{Yeni Annenin Benlik Sunumu}

Performansların kullanım amacı bir rolü sergilemek, oynamaktır. Bu benlik sunumunun örneklemine iki kadın profili alınmıştır. Bu profiller yeni anne rolü oynamakta ve seyircisi olan takipçi bireylere sunmaktadır. Bir araştırmacı olarak bu grubun hikâyeleri incelenen 18 aktörde şu tespitler yapılabilmektedir: Hikâyeleri incelenen aktörlerimizden biri günde ortalama 5 diğeri 10 ve üzeri hikâye paylaşımı yapmaktadır. Fotoğrafların arka planında çocuk odası, çocuk oyuncakları, mama masası, bebek eşyaları kullanılmıştır. Kişisel vitrinleri: her ikisi de otuzlu yaşlarda, makyajlı, iyi giyimli, bakımlı, maddi yönden iyi görünümlüdür. Mutlu, heyecanlı ve eğlenmeyi seven bir performans sergilemektedir. Dramatik canlandırma; her iki kadın da bakımlı, gezmeyi seven ve neşeli bir kadın sunumu benliği yansıtmaktadır. İdealize etme; her iki kadın da bebeklerinin sağlıklı beslendiğini gösteren, bebeklerine çokça vakit ayırdığını ve ilgili bir anne olduğu inancının yaratılmasına uygun davranmaktadır. İfade denetimi; her iki kadın da kendinden çok bebek eşyalarını, kıyafetlerini ve bebeklerini gösteren hikâyeler paylaşmaktadır. Her iki aktörün performansları Barthes'ın göstergebilim analizi ile değerlendirildiğinde daha iyi anlaşılmaktadır;

\section{Yeni Annenin Benlik Sunumunun Göstergebilimsel İncelenmesi}

\begin{tabular}{|c|c|c|c|c|c|}
\hline Gösterge & İnsan & Mekân & Konu & Araç & Zemin \\
\hline Gösteren & Yeni Anne & $\begin{array}{c}\text { Ev, Oyun } \\
\text { Alanları, Açık } \\
\text { Alanlar }\end{array}$ & $\begin{array}{c}\text { Bebeğin yeni } \\
\text { doğmuş olması, } \\
\text { bebekle birlikte } \\
\text { gelen değişim }\end{array}$ & $\begin{array}{c}\text { Bebek Eşyaları, } \\
\text { kıyafetleri }\end{array}$ & $\begin{array}{c}\text { Evin bebek oda- } \\
\text { sı, bebekli park } \\
\text { alanları }\end{array}$ \\
\hline Gösterilen & $\begin{array}{c}\text { Masumiyet, } \\
\text { neşe, heyecan, } \\
\text { sevgi }\end{array}$ & Güven, huzur & $\begin{array}{c}\text { Bebeğin güzelliği, } \\
\text { zenginlik, sağlıklı } \\
\text { beslenme, gezme }\end{array}$ & $\begin{array}{c}\text { Bebeğin önemi, } \\
\text { iyi giyindiği, iyi } \\
\text { oyuncaklarının } \\
\text { olduğu }\end{array}$ & $\begin{array}{c}\text { Bebeğe ait bir } \\
\text { odanın oluşu }\end{array}$ \\
\hline
\end{tabular}

\begin{tabular}{|c|l|l|}
\hline \multicolumn{1}{|c|}{ Düz Anlam } & \multicolumn{1}{|c|}{ Yan Anlam } & \multicolumn{1}{c|}{ Hikâye Anlatımı } \\
\hline Yeni doğmuş bir bebek & $\begin{array}{l}\text { Bebeğin güzelliği, iyi koşullar, ihtiyaç } \\
\text { duyulan her şeyin var oluşu }\end{array}$ & $\begin{array}{l}\text { Yeni anne profilleri bebeklerini ön } \\
\text { plana çıkarmakta ve takipçilerine } \\
\text { iyi bir anne performansı sunmak- } \\
\text { tadır }\end{array}$ \\
\hline
\end{tabular}

Barthes'a göre gösterge, gösterilen ve gösteren ilişkisinden ortaya çıkmaktadır (Barthes, 2014, 47). Yeni anne göstergesi bu ilişki çerçevesinde incelendiğinde düz anlamda anne ve yeni doğmuş bir bebek ifade edilirken, yan anlamlarda bebeğin güzel olduğu, sağliklı beslendiği, gelişimi için gerekli oyuncakların alındığı gibi anlamlar ortaya çıkmaktadır. 


\section{Yeni Evlinin Benlik Sunumu}

$\mathrm{Bu}$ benlik sunumunun örneklemine iki kadın profili alınmıştır. Bu profiller yeni evli rolü oynamakta ve performansını günlük olarak seyircisiyle buluşturmaktadır. Bir araştırmacı olarak bu grubun hikâyeleri incelendiğinde şu tespitler yapılabilmektedir: Hikâyeleri incelenen aktörlerimizden biri günde ortalama 15 diğeri 20-25 arasında hikâye paylaşımı yapmaktadır. Fotoğrafların setinde yani arka planında mutfak eşyaları, yemek masası takımı, gösterişli perdeler, renk uyumlu salonlar, evin dekore edilmiş alanları görülmektedir. Kişisel vitrinleri; her ikisi de yirmili yaşlarda, biri muhafazakâr, diğer daha açık giyimli, her ikisi de bakımlı, takı takmayı seven, makyajlı, zayıf, güler yüzlü, modaya uygun giyimli aktörlerdir. Dramatik canlandırma; diğerine göre muhafazakâr olan kapalı giysilerinin ön plana çıktığı, altın takılarının, altın rengi masa sunum takımlarının ve pahalı makyaj ürünlerinin yer aldığı bir sunum sergilemektedir. İdealize etme; ev dekorasyon ve eşyalarının, altın takıların ön plana çıktığ1 performanslar görülmektedir. Yanlış sunum ve ifade denetimi; her iki aktörün de evine ilişkin paylaşımda bulunurken, ev eşyasını aldığı ya da özel bir dekore sipariș verdiği profili etiketlemesi performansların inandırııılığını artırmaktadır. Her iki aktörün performansları Barthes'ın göstergebilim analizi ile değerlendirildiğinde daha iyi anlaşılmaktadır;

Yeni Evlinin Benlik Sunumunun Göstergebilimsel İncelenmesi

\begin{tabular}{|c|c|c|c|c|c|}
\hline Gösterge & İnsan & Mekân & Konu & Araç & Zemin \\
\hline Gösteren & Yeni Evli & $\begin{array}{l}\text { Oturma Odası, } \\
\text { Banyo, Mutfak }\end{array}$ & $\begin{array}{l}\text { Eşyaların yeni } \\
\text { ve uyumlu ol- } \\
\text { ması, pahalı } \\
\text { eşyalar, altın } \\
\text { takılar }\end{array}$ & $\begin{array}{l}\text { Takı, makyaj } \\
\text { ürünleri, } \\
\text { Mutfak ürünleri, } \\
\text { ev eşyası, kıya- } \\
\text { fet, aile albümü, } \\
\text { fincan takımı, } \\
\text { yemek masası, } \\
\text { markalı eşyalar, } \\
\text { özel dekoratif } \\
\text { eşyalar, gösterişli } \\
\text { perdeler }\end{array}$ & $\begin{array}{l}\text { Oturma Odası, } \\
\text { Banyo, Mutfak }\end{array}$ \\
\hline Gösterilen & $\begin{array}{l}\text { Bakım, zen- } \\
\text { ginlik, } \\
\text { mutluluk, } \\
\text { aşk, } \\
\text { heyecan }\end{array}$ & $\begin{array}{l}\text { Uyum, zengin- } \\
\text { lik, zevk, dekor }\end{array}$ & $\begin{array}{l}\text { Gösteriş, zen- } \\
\text { ginlik, güzellik, } \\
\text { iyi giyim, } \\
\text { dekoratif zevk }\end{array}$ & $\begin{array}{l}\text { İyi ve zengin } \\
\text { yaşam, uyumlu } \\
\text { ev, tamlık }\end{array}$ & $\begin{array}{l}\text { Evin yeni oluşu, } \\
\text { uyum, dekor }\end{array}$ \\
\hline \multicolumn{2}{|c|}{ Düz Anlam } & \multicolumn{2}{|c|}{ Yan Anlam } & \multicolumn{2}{|c|}{ Hikâye Anlatımı } \\
\hline \multicolumn{2}{|c|}{ Yeni evli kadın } & \multicolumn{2}{|c|}{$\begin{array}{l}\text { Altın takıların olması, evin yeni } \\
\text { oluşu, uyum, iyi kalitede hayat, } \\
\text { tamlık }\end{array}$} & \multicolumn{2}{|c|}{$\begin{array}{l}\text { Yeni evli kadın profilleri performans- } \\
\text { larında ev dekorasyonlarını ve takıla- } \\
\text { rını ön plana çıkarmakta, takipçile- } \\
\text { rine uyumsuzluk, eksiklik gösterme- } \\
\text { mektedir. }\end{array}$} \\
\hline
\end{tabular}

Yeni evli göstergesi gösteren gösterilen çerçevesinde incelendiğinde düz anlamda yeni evli iki çift ifade edilirken, yan anlamlarda evin iyi bir dekorda ve eşyaların uyumlu olduğu, pahalı

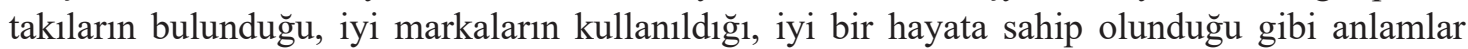
ortaya çıkmaktadır. 


\section{Çok Gezenlerin Benlik Sunumu}

$\mathrm{Bu}$ benlik sunumunun örneklemine iki kadın, bir erkek profili alınmıştır. Bu profiller zengin rolü oynamakta ve performansını günlük olarak seyircisiyle buluşturmaktadır. Bir araştırmacı olarak bu grubun hikâyeleri incelendiğinde şu tespitler yapılabilmektedir: Hikâyeleri incelenen aktörlerimizden erkek profil günde ortalama 15, kadın profiller günde 25 hikâye paylaşımı yapmaktadır. Fotoğrafların setinde doğa, tarihi yapılar, deniz, farklı milletten insanlar, farklı giyimli insanlar, devasa binalar, yabancı isimlerde dükkânlar, farklı görünümlü yiyecek ve objeler görülmektedir. Kişisel vitrinleri; erkek profil iyi giyimli, güler yüzlü, uzun boylu, atletik vücutlu, esmer; kadın profillerden biri kumral, beyaz tenli, uzun boylu, güler yüzlü, renkli gözlü, iyi giyimli, bakımlı makyajlı diğeri; fotoğraflarda öz çekimlere daha sık yer veren, gözlüklü, yer yer giyimine uygun güneș gözlüğü takan, spor görünümlü, neșeli bir vitrin sunmaktadır. Dramatik canlandırma; her üç profilin de hikâye paylaşımlarında gezdikleri yerlerin önünde öz çekim (selfie) paylaştı̆̆ yapıldığ 1 görülmektedir. İfade Denetimi; Her üç profilin de hikâye paylașımlarında gece hayatı bulunmaktadır. Fakat profillerin burada yaptıkları paylaşımlarda kötü alıșkanlıklarını ön plana çıkarmayan ve daha çok mekân ismi ve görselinin yer aldığı paylașımlar içeren hikâyeleri, aktörün performansına olan inandırıcılığını artırmaktadır. Yanlıș Sunum; aktörlerden erkek profilin günlük paylaşımlarında, zaman zaman evine yer vermesi çok gezen benlik sunumuyla uyuşmamaktadır. Her iki aktörün performansları Barthes'ın göstergebilim analizi ile değerlendirildiğinde daha iyi anlaşılmaktadır;

\section{Çok Gezen Benlik Sunumunun Göstergebilimsel İncelenmesi}

\begin{tabular}{|c|c|c|c|c|c|}
\hline Gösterge & İnsan & Mekân & Konu & Araç & Zemin \\
\hline Gösteren & $\begin{array}{l}\text { Çok Gezen, } \\
\text { Farklı Giyimli } \\
\text { İnsanlar }\end{array}$ & $\begin{array}{l}\text { Mimari yapılar, } \\
\text { deniz, } \\
\text { doğa, manzara, } \\
\text { devasa yapılar, }\end{array}$ & $\begin{array}{l}\text { Yeni yerlerin keşfe- } \\
\text { dilmesi, yeni insan- } \\
\text { larla tanışma, farklı } \\
\text { türden lezzetler tat- } \\
\text { ma, }\end{array}$ & $\begin{array}{l}\text { Uçak, } \\
\text { Araba, } \\
\text { Bisiklet, }\end{array}$ & $\begin{array}{l}\text { Farklı ülkeler, } \\
\text { Farklı şehirler }\end{array}$ \\
\hline Gösterilen & $\begin{array}{l}\text { Merakl1, neşe- } \\
\text { li, gezen, yeni } \\
\text { yerler, keşif, } \\
\text { heyecan, yeni } \\
\text { yerler }\end{array}$ & $\begin{array}{l}\text { Beğeni, gör- } \\
\text { kem, hayranlık, } \\
\text { uyum, mutlu- } \\
\text { luk, } \\
\text { eğlence }\end{array}$ & $\begin{array}{l}\text { Gezmenin verdiği } \\
\text { mutluluk, hayran } \\
\text { olma, paylaşım }\end{array}$ & $\begin{array}{l}\text { Seyahat sira- } \\
\text { sında çeşitli } \\
\text { yollar kullan- } \\
\text { ma, uzak yer- } \\
\text { lere gitme }\end{array}$ & $\begin{array}{l}\text { Gezilmesi ge- } \\
\text { reken yerler }\end{array}$ \\
\hline
\end{tabular}

\begin{tabular}{|l|l|l|}
\hline Düz Anlam & Yan Anlam & Hikâye Anlatımı \\
\hline Çok gezen bireyler & $\begin{array}{l}\text { Gezmeyi sevmek, eğlenceli hayat, } \\
\text { heyecan }\end{array}$ & $\begin{array}{l}\text { Çok gezenlerin performanslarında eğ- } \\
\text { lenceli hikâyeler ön plana çıkmakta, ak- } \\
\text { törler seyircisi ile gezdiği yerleri çeşitli } \\
\text { duygu ikonları ile paylaşmaktadır. }\end{array}$ \\
\hline
\end{tabular}

Çok gezenlerin benlik sunumu gösteren ve gösterilen ilişkisi çerçevesinde incelendiğinde düz anlamda her üç profilinde gezmeyi sevdiği ifade edilirken, yan anlamlarda gezmenin verdiği mutluluk, yeni yerler keşfetme heyecanı, eğlenceli yerlerde bulunulduğu gibi anlamlar ortaya çıkmaktadır.

\section{Alışverişkoliklerin Benlik Sunumu}

Alışverişkoliklerin benlik sunumunun örneklemine iki kadın profil alınmıştır. $\mathrm{Bu}$ profiller sık alışveriş yapma ve alınan ürünleri paylaşma rolü oynamakta ve performansını günlük olarak seyircisiyle buluşturmaktadır. Bu grubun hikâyeleri incelendiğinde şu tespitler yapılabilmektedir: Hikâyeleri incelenen kadın aktörlerin günde ortalama 25 hikâye paylaşımı yaptığ1 görülmektedir. Bu paylaşım oranının alışveriş yapılan günlerde arttı̆̆g gözlenmektedir. 
Paylaşımların setinde; arka planda Avm (alışveriş merkezi), Avm mağazaları, mağazaların yoğun olduğu sokaklar, Nişantaşı, Bebek, Sarıyer gibi semtler, lüks arabalar, çanta dükkânları, alışveriş poşetleri, kıyafet dolabı, ayakkabı dolabında çeşitli markalarda ayakkabılar yer almaktadır. Kişisel vitrinleri; her ikisi de yirmili yaşlarda, oldukça bakımlı, saçları sarı, modaya uygun giyimli, gösterişli takılar takan, marka gözlükleri bulunan ve her kıyafete uygun gözlük takan, özçekim paylaşımları seven, makyajsız fotoğraflardan kaçınan, lüks yerlerde paylaşım yapan, gezmeyi seven bir sunum sergilemektedirler. Dramatik canlandırma; aldıkları ürünleri giyerek ve fotoğrafını çekerek sergileyen her iki profil, hikâye paylaşımlarında çeşitli markaları etiketlemektedir. İdealize etme; her iki kadın profil, pahalı markalarda ayakkabı ve çantalar kullandığı paylaşımları ön plana alan, gösterişli ve büyük aksesuarlar takan, alışveriş merkezleri ve toplum tarafından elit yerler olarak tanımlanan semtlerde hikâyeler paylaşmayı tercih etmiştir. Her iki aktörün performansları Barthes'ın göstergebilim analizi ile değerlendirildiğinde daha iyi anlaşılmaktadır;

\section{Alışverişkoliklerin Benlik Sunumunun Göstergebilimsel İncelenmesi}

\begin{tabular}{|c|c|c|c|c|c|c|}
\hline Gösterge & İnsan & Mekân & \multicolumn{2}{|l|}{ Konu } & Araç & Zemin \\
\hline Gösteren & $\begin{array}{l}\text { Alışveriş Yapma- } \\
\text { yı Seven }\end{array}$ & $\begin{array}{l}\text { Avm, } \\
\text { Bebek, } \\
\text { Nişantaşı, } \\
\text { City's, } \\
\text { Sarıyer }\end{array}$ & \multicolumn{2}{|c|}{$\begin{array}{l}\text { Alışveriş paylaşımı } \\
\text { yapılması, ürünlerin } \\
\text { gösterilmesi, mo- } \\
\text { daya uyum, pahalı } \\
\text { kıyafetler, gösterişli } \\
\text { aksesuarlar }\end{array}$} & $\begin{array}{l}\text { Telefon, alış- } \\
\text { veriş poşeti, } \\
\text { ayakkabı, } \\
\text { çanta }\end{array}$ & $\begin{array}{l}\text { Alışveriş ma- } \\
\text { ğazaları, işlek } \\
\text { sokaklar, lüks } \\
\text { kafeleri }\end{array}$ \\
\hline Gösterilen & $\begin{array}{l}\text { Marka Göste- } \\
\text { rimi, zenginlik, } \\
\text { bakımlılık, mo- } \\
\text { daya uyum, } \\
\text { Gezmeyi seven, } \\
\text { Lüks düşkünlü- } \\
\text { ğü }\end{array}$ & $\begin{array}{l}\text { Mutluluk, eğ- } \\
\text { lence, neşe, } \\
\text { lüks yerler- } \\
\text { den alışveriş } \\
\text { yapma }\end{array}$ & \multicolumn{2}{|c|}{$\begin{array}{l}\text { Zenginlik, trend } \\
\text { ürünler, pahalı me- } \\
\text { kanlar }\end{array}$} & $\begin{array}{l}\text { Markaların } \\
\text { takip edilme- } \\
\text { si, modaya } \\
\text { uyum, pahalı } \\
\text { ürünler }\end{array}$ & $\begin{array}{l}\text { Alışveriş için } \\
\text { uygun, göste- } \\
\text { rişli mekânlar }\end{array}$ \\
\hline \multicolumn{2}{|l|}{ Düz Anlam } & \multicolumn{2}{|l|}{ Yan Anlam } & \multicolumn{3}{|c|}{ Hikâye Anlatımı } \\
\hline \multicolumn{2}{|c|}{ Aşırı alışveriş yapan bireyler } & \multicolumn{2}{|c|}{$\begin{array}{l}\text { Zenginlik, moda takibi, } \\
\text { uyum, popüler ürünler }\end{array}$} & \multicolumn{3}{|c|}{$\begin{array}{l}\text { Alışverişkoliklerin performans sunum- } \\
\text { larında takı, giyisi ve alışveriş mekanla- } \\
\text { rı dikkat çekmektedir. Alışverişkolikler } \\
\text { hikâye sunumlarında marka etiketi ve } \\
\text { konum bildirimini sık kullandıkları göz- } \\
\text { lenmektedir. }\end{array}$} \\
\hline
\end{tabular}

Alışverişkoliklerin benlik sunumu, düz anlamda alışveriş yapmayı seven iki kadın ifade edilirken, yan anlamlarda lüks yerlerden alışveriş yapıldığı, modaya uyulduğu, pahalı ürünler kullanıldığı gibi anlamlar ortaya çıkmaktadır.

\section{Gösterișçilerin Benlik Sunumu}

Gösterişçilerin benlik sunumunun örneklemine iki kadın ve iki erkek profil alınmıştır. Bir araştırmacı olarak bu grubun hikâyeleri incelendiğinde şu tespitler yapılabilmektedir: Hikâyeleri incelenen kadın aktörlerin günde ortalama 20, erkek profillerin ise 20-25 arası hikâye paylaşımı yaptığı görülmektedir. Bu paylaşım oranını günlük aktivitelere bağlı olarak değişkenlik göstermektedir. Paylaşımların setinde; arka planda elit restoranlar, pahalı evler, lüks eşyalar, pahalı araba anahtarları, pahalı ayakkabılar, pahalı takı ve çantalar, Nişantaşı, Bebek gibi semtler, alışveriş merkezleri, çeşitli markalarda gözlükler, kıyafet dolapları ve spor salonları yer almaktadır. Kişisel vitrinleri; her ikisi kadın aktör yirmili yaşlarda, oldukça bakımlı, modaya uyumlu giyinen, popüler ve pahalı takı, şapka, gözlük kullanan, saçları günün 
popüler kesim ve boyasına uygun görünümlü kişilerdir. Dramatik canlandırma: kadın aktörler gezen ve alışveriş yapan, aldıkları yeni ürünleri kalpli, efektli ve duygu ikonlu olarak paylaşan, konum bildirimlerinde bulunan ve sıç̧a markaları etiketleyen, farklı ülkeler, etkinlikler ve lüks semtlerde arkadaşlarıyla vakit geçiren, modaya uyumlu ve pahalı popüler ürünleri seyircisine sergilerken; erkek profiller sıkça lüks arabalarda özçekim yapan, pahalı gözlükler takan, bileklik ve ayakkabılarını ön plana çıkaran, lüks yerlerde ve alışveriş merkezlerinde konum bildirimleri yapan, gece hayatlarının olduğuna dair paylaşımlarda bulunmuştur. Erkek profillerin gece saatlerindeki hikâye sunumlarında alkol ve kötü alışkanlıklarla ön plana çıkmamaya özen gösterdiği gözlenmiştir. İfade denetiminde aktörün, seyirciyle etkileşime açık olacak şekilde marka etiketli ve konum bildirimlerine yer vermesi, seyircinin kendisine duyduğu inandırıcılığı artırmaktadır. Her iki aktörün performansları Barthes'ın göstergebilim analizi ile değerlendirildiğinde daha iyi anlaşılmaktadır;

\section{Gösterişçilerin Benlik Sunumunun Göstergebilimsel İncelenmesi}

\begin{tabular}{|c|c|c|c|c|c|c|c|}
\hline Gösterge & \multicolumn{2}{|l|}{ İnsan } & Mekân & \multicolumn{2}{|l|}{ Konu } & Araç & Zemin \\
\hline Gösteren & \multicolumn{2}{|c|}{$\begin{array}{l}\text { Marka, yer ve } \\
\text { ürün içeren } \\
\text { hikâye sunum- } \\
\text { ları }\end{array}$} & $\begin{array}{l}\text { Avm, } \\
\text { Bebek, } \\
\text { Nişantaşı, } \\
\text { City's, } \\
\text { Sarıyer, } \\
\text { Dublex ev, } \\
\text { Rezidans, } \\
\text { Oto Galeri, } \\
\text { Konser, } \\
\text { Bar, } \\
\text { Restoran }\end{array}$ & \multicolumn{2}{|c|}{$\begin{array}{l}\text { Lüks içeren payla- } \\
\text { şımlar yapılması, } \\
\text { ürünlerin göste- } \\
\text { rilmesi, modaya } \\
\text { uyum, pahalı kı- } \\
\text { yafetler, gösterişli } \\
\text { aksesuarlar, pahalı } \\
\text { arabalar }\end{array}$} & $\begin{array}{l}\text { Telefon, Alış- } \\
\text { veriş poşeti, } \\
\text { Ayakkabı, } \\
\text { Çanta, } \\
\text { Gözlük, } \\
\text { Araba, } \\
\text { Anahtarlık, }\end{array}$ & $\begin{array}{l}\text { Alışveriş ma- } \\
\text { ğazaları, işlek } \\
\text { sokaklar, lüks } \\
\text { restoranlar, } \\
\text { lüks evler, ga- } \\
\text { leriler, sergi ve } \\
\text { konser alanları }\end{array}$ \\
\hline Gösterilen & $\begin{array}{l}\text { Marka } \\
\text { rimi, ze } \\
\text { bakımlıl } \\
\text { daya uyı } \\
\text { Lüks dü } \\
\text { ğü, } \\
\text { Lüks } \\
\text { içme, } \\
\text { Zengin } \\
\text { daşlar }\end{array}$ & $\begin{array}{l}\text { Göste- } \\
\text { ginlik, } \\
\text { mo- } \\
\text { m, } \\
\text { künlü- } \\
\text { yeme } \\
\text { arka- }\end{array}$ & $\begin{array}{l}\text { Mutluluk, eğ- } \\
\text { lence, neşe, } \\
\text { lüks yerlerden } \\
\text { alışveriş yap- } \\
\text { ma }\end{array}$ & $\begin{array}{l}\text { Trend } \\
\text { ürünler, } \\
\text { mekânlar, } \\
\text { yaşam }\end{array}$ & $\begin{array}{l}\text { pahalı } \\
\text { pahalı } \\
\text { zengin }\end{array}$ & $\begin{array}{l}\text { Markaların } \\
\text { takip edilme- } \\
\text { si, modaya } \\
\text { uyum, pahalı } \\
\text { ürünler, } \\
\text { Eğlenceli arka- } \\
\text { daşlar, hobi }\end{array}$ & $\begin{array}{l}\text { G ö s t e r i ş I i } \\
\text { mekânlar, elit- } \\
\text { lik }\end{array}$ \\
\hline \multicolumn{2}{|l|}{ Düz Anlam } & \multicolumn{3}{|c|}{ Yan Anlam } & \multicolumn{3}{|c|}{ Hikâye Anlatımı } \\
\hline \multicolumn{2}{|c|}{ Gösteriş yapan bireyler } & $\begin{array}{l}\text { Zengir } \\
\text { püler } \\
\text { yatınır }\end{array}$ & $\begin{array}{l}\text { lik, moda takibi, } \\
\text { üünler, lüks hay } \\
\text { olması, bakımlı }\end{array}$ & $\begin{array}{l}\text { uyum, po- } \\
\text { at, gece ha- } \\
\text { lık }\end{array}$ & \multicolumn{3}{|c|}{$\begin{array}{l}\text { Alışverişkoliklerin performans sunum- } \\
\text { larında takı, giyisi ve alışveriş mekanla- } \\
\text { rı dikkat çekmektedir. Alışverişkolikler } \\
\text { hikâye sunumlarında marka etiketi ve } \\
\text { konum bildirimini sık kullandıkları göz- } \\
\text { lenmektedir. }\end{array}$} \\
\hline
\end{tabular}

Gösterişçilerin benlik sunumu, düz anlamda gösterişi seven iki kadın ve iki erkek aktör ifade edilirken; yan anlamlarda lüks düşkünlüğü, zenginlik, elitlik, modaya uyum, herkesçe bilinen pahalı markaların tercih edildiği, basit yerlerde konum bildirimi yapmaktan çekinildiği, kadın aktörlerin makyajsız ve bakımsız hikâye sunumundan kaçındığı, arkadaş gruplarının da zengin olduğu gibi anlamlar ortaya çıkmaktadır. 


\section{Kendini Gösterenlerin Benlik Sunumu}

Bir araştırmacı olarak bu grubun hikâyeleri incelendiğinde şu tespitler yapılabilmektedir: Hikâyeleri incelenen aktörlerimizden kadın profil günde ortalama 30, erkek profiller günde ortalama 15-20 hikâye paylaşımı yapmaktadır. Fotoğrafların arka planında dekor, renkli eşyalar, cafe, tarihi yapılar, deniz, kuaför, spor salonları, yatak odası, banyo, iyi marka arabaların kullanıldığı gözlemlenmektedir. Kişisel vitrinleri: erkek profillerin her ikisi de otuzlu yaşlarda, mutlu, yüz hatları düzgün, iyi giyimli, bakımlı, maddi yönden iyi görünümlüdür. Dramatik canlandırma; her iki erkek bakımlı, modaya uyumlu, küpe takan, gezmeyi seven, spor yapan, deniz ve havuza giren, gece hayatında arkadaşlarıyla vakit geçiren, sıkça selfie paylaşan benlik sunumu sergilemektedir. Kendini gösterenler grubu selfie paylaşımları ve video çekimlerinde ön planda kendilerini göstermeleriyle, gösterişçiler grubundan ayrıșmaktadır. İdealize etme; Her iki erkek aktörün de hikâyelerinde elit yerlerde kendini göstermesi, bakımsız hikâye paylaşımı yapmaması, gece hayatında kötü alışkanlıkları ve toplum değerlerine ters düşebilecek görüntüleri paylaşmaması performanslarını idealize ettiklerini göstermektedir. Her iki aktörün performansları Barthes'ın göstergebilim analizi ile değerlendirildiğinde daha iyi anlaşılmaktadır;

Kendini Gösterenlerin Benlik Sunumunun Göstergebilimsel İncelenmesi

\begin{tabular}{|c|c|c|c|c|c|c|c|}
\hline Gösterge & \multicolumn{2}{|l|}{ İnsan } & Mekân & \multicolumn{2}{|l|}{ Konu } & Araç & Zemin \\
\hline Gösteren & $\begin{array}{l}\text { Selfie } \\
\text { ları }\end{array}$ & sunum- & $\begin{array}{l}\text { Spor salonu, } \\
\text { Güzellik salonu, } \\
\text { Kuaför, } \\
\text { Ev, } \\
\text { Restoran, eğlen- } \\
\text { ce mekânları }\end{array}$ & $\begin{array}{l}\text { Elit yerlerd } \\
\text { paylaşımı, } \\
\text { daşlarla eg } \\
\text { vakit geçir } \\
\text { bilerin sı } \\
\text { trend akse } \\
\text { rın kullanı } \\
\text { bakımına } \\
\text { verme }\end{array}$ & $\begin{array}{l}\text { le selfie } \\
\text { arka- } \\
\text { ğlenceli } \\
\text { me, ho- } \\
\text { unumu, } \\
\text { esuarla- } \\
\text { mı, cilt } \\
\text { önem }\end{array}$ & $\begin{array}{l}\text { Smile ikonu, } \\
\text { Gözlüklü gü- } \\
\text { I ü m s e m e } \\
\text { ikonu, spor } \\
\text { aletleri, mak- } \\
\text { yaj malzeme- } \\
\text { leri, cilt bakım } \\
\text { ürünleri, akse- } \\
\text { suar, } \\
\text { küpe }\end{array}$ & $\begin{array}{l}\text { Ev, spor salo- } \\
\text { nunda fitness } \\
\text { alanı, deniz } \\
\text { kenarı, havuz, } \\
\text { kuaför, cafe }\end{array}$ \\
\hline Gösterilen & $\begin{array}{l}\text { Bakımlılıl } \\
\text { Aksesuar } \\
\text { nımı, } \\
\text { Marka } \\
\text { mi, } \\
\text { Pahalı ür } \\
\text { Mutluluk } \\
\text { Eğlenceli } \\
\text { Gezmeyi } \\
\text { Heyecanl } \\
\text { den keyi } \\
\text { arkada } \\
\text { olmaktar } \\
\text { lanan }\end{array}$ & $\begin{array}{l}\text { k, } \\
\text { güla- } \\
\text { gösteri- } \\
\text { ünler, } \\
\text {, hayat, } \\
\text { seven, } \\
\text { lı, tatil- } \\
\text { if alan, } \\
\text { şl a rla } \\
1 \text { hoş- }\end{array}$ & $\begin{array}{l}\text { Mutluluk, eğ- } \\
\text { lence, neşe, } \\
\text { hobi sahibi } \\
\text { olma, uyum, } \\
\text { kendini önem- } \\
\text { seme }\end{array}$ & $\begin{array}{l}\text { Zenginlik, } \\
\text { ürünler, } \\
\text { mekanlar }\end{array}$ & $\begin{array}{l}\text { trend } \\
\text { pahalı }\end{array}$ & & $\begin{array}{l}\text { Alışveriş için } \\
\text { uygun, göste- } \\
\text { rişli mekânlar }\end{array}$ \\
\hline \multicolumn{2}{|l|}{ Düz Anlam } & \multicolumn{3}{|c|}{ Yan Anlam } & \multicolumn{3}{|c|}{ Hikâye Anlatımı } \\
\hline \multicolumn{2}{|c|}{$\begin{array}{l}\text { Hikâye sunumunda } \\
\text { kendisini gösteren bi- } \\
\text { reyler }\end{array}$} & \multicolumn{3}{|c|}{$\begin{array}{l}\text { Eğlenmeyi seven, takı ve aksesuar } \\
\text { takmayı önemseyen, modaya uyum } \\
\text { sağlayan, elit yerlerde bulunan, ar- } \\
\text { kadaşlarıyla olmaktan mutlu olan, } \\
\text { dış görünümüne önem veren birey- } \\
\text { ler }\end{array}$} & \multicolumn{3}{|c|}{$\begin{array}{l}\text { Kendini gösterenlerin hikâye sunumların- } \\
\text { da duygu ikonları, kişi ve marka etiketleri, } \\
\text { yer bildirimlerinin sıkça kullanıldığı göz- } \\
\text { lemlenmektedir. }\end{array}$} \\
\hline
\end{tabular}


Kendini gösterenlerin benlik sunumu, düz anlamda selfie paylaşan bireyleri ifade ederken; yan anlamlarda bakımlı olma, eğlenceli görünme, iyi bir hayat sürme, kaliteli cilt bakım ürünleri kullanma, dış görünümüne özen gösterme gibi anlamları ifade etmektedir.

\section{Zenginlerin Benlik Sunumu}

Performansların kullanım amacı bir rolü sergilemek, oynamaktır. Bu benlik sunumunun örneklemine iki erkek profil alınmıştır. Bir araştırmacı olarak bu grubun hikâyeleri incelendiğinde şu tespitler yapılabilmektedir: Hikâyeleri incelenen erkek profillerin günde ortalama 10-15 aras1 hikâye paylaşımı yaptığı görülmektedir. Paylaşımların setinde; Starbucks gibi kahve mekânları, araba, güzel dekore edilmiş ev, pahalı eşya, Nişantaşı, Akmerkez, Bebek gibi yerler, yat, spor salonu, kıyafet dolabı yer almaktadır. Kişisel vitrinleri; her iki erkek aktör otuzlu yaşlarda şık giyimli, tarz sahibi, esmer ve saç kesimleri günün modasına uyumlu, atletik yapıl1, spor giyimli, güneş gözlüğü kullanan, küpe ve bileklik gibi aksesuarlar takan, spor yapan, gezmeyi seven bir sunum sergilemektedirler. Dramatik canlandırma: Her iki aktör de gezmeyi seven, arkadaşlarıyla sıkça vakit geçiren, lüks mekânlarda bulunan, spor araba kullanan, gece hayatları bulunan ve dış görünüşe önem veren performanslar sergilemektedir. İdealize etme; Aktörlerin özellikle gece hayatlarını anlatan hikâye paylaşımlarında, toplum değer yargıları ve beklentilerine ters düşmeyecek performanslar sergilediği gözlemlenmektedir. İfade denetimi ve yanlış sunum; Her iki aktörün incelendiği zaman dilimindeki performans sunumlarına bakıldığında, konum bildirimi ve marka etiketine çok az yer verdiği gözlemlenmekte; daha çok marka amblemleri, alışveriş poşetleri, bilindik alışveriş merkezleri, markası bilinen takı ve aksesuarların ön plana çıktığı hikâyeler sunulmaktadır. Paylaşımların setleri düzgündür fakat konum ve etiketleme etkileşimlerinin nadir görülmektedir. İfade denetimindeki bu eksiklik değerlendirildiğinde aktörlerin yanlış sunum yaptıkları söylenebilir. Her iki aktörün performansları Barthes'ın göstergebilim analizi ile değerlendirildiğinde daha iyi anlaşılmaktadır;

\section{Zenginlerin Benlik Sunumunun Göstergebilimsel İncelenmesi}

\begin{tabular}{|c|c|c|c|c|c|}
\hline Gösterge & İnsan & Mekân & Konu & Araç & Zemin \\
\hline Gösteren & $\begin{array}{l}\text { Marka, yer ve } \\
\text { ürün içeren } \\
\text { hikâye sunum- } \\
\text { ları }\end{array}$ & $\begin{array}{l}\text { Avm, } \\
\text { Bebek, } \\
\text { Nişantaşı, } \\
\text { Deniz kenarı, } \\
\text { Liman } \\
\text { Rezidans, } \\
\text { Lüks restoran, } \\
\text { Spor salonu, } \\
\text { Bar, } \\
\text { Starbucks }\end{array}$ & $\begin{array}{l}\text { Pahalı ürün- } \\
\text { lerin gösteril- } \\
\text { mesi, modaya } \\
\text { uyum, pahalı } \\
\text { kıyafetler, pa- } \\
\text { halı arabalar, } \\
\text { zengin bir ha- } \\
\text { yat }\end{array}$ & $\begin{array}{l}\text { Araba anah- } \\
\text { tarı, küpe, bi- } \\
\text { leklik, güneş } \\
\text { gözlüğü, kahve } \\
\text { bardağı, mar- } \\
\text { ka ayakkabı, } \\
\text { spor araba, } \\
\text { kıyafet dolabı, } \\
\text { yat }\end{array}$ & $\begin{array}{l}\text { Alışveriş mağaza- } \\
\text { ları, işlek sokaklar, } \\
\text { lüks restoranlar, } \\
\text { lüks evler, bar, gece } \\
\text { mekânları, araba içi }\end{array}$ \\
\hline Gösterilen & $\begin{array}{l}\text { Marka Göste- } \\
\text { rimi, zenginlik, } \\
\text { modaya uyum, } \\
\text { Lüks yeme } \\
\text { içme, } \\
\text { Zengin arka- } \\
\text { daşlar, }\end{array}$ & $\begin{array}{l}\text { Mutluluk, eğ- } \\
\text { lence, neşe, } \\
\text { lüks yerlerden } \\
\text { alışveriş yap- } \\
\text { ma }\end{array}$ & $\begin{array}{l}\text { Trend pahalı } \\
\text { ürünler, pahalı } \\
\text { mekânlar, zen- } \\
\text { gin yaşam }\end{array}$ & $\begin{array}{l}\text { Markaların } \\
\text { takip edilme- } \\
\text { si, modaya } \\
\text { uyum, pahalı } \\
\text { ürünler, } \\
\text { Eğlenceli arka- } \\
\text { daşlar, hobi }\end{array}$ & $\begin{array}{l}\text { Gösterişlimekânlar, } \\
\text { elitlik, zengin ya- } \\
\text { şam }\end{array}$ \\
\hline
\end{tabular}

\begin{tabular}{|l|l|l|}
\hline Düz Anlam & Yan Anlam & Hikâye Anlatımı \\
\hline \multirow{5}{*}{ Zengin bireyler } & Zenginlik, moda takibi, uyum, pahalı & Zenginlerin performans sunumlarında pahalı \\
& ürün kullanımı, dış görünüşe önem & araba anahtarlı, eli yerler, pahalı aksesuarlar, \\
& $\begin{array}{l}\text { verme, gece hayatının olması, zen- } \\
\text { pan yaşam, hayat kalitesinin yüksek } \\
\end{array}$ & $\begin{array}{l}\text { oluşu } \\
\text { rin hikâye sunumlarında beklenenin aksine } \\
\text { marka etiketi ve konum bildirimini daha az } \\
\text { olduğu gözlemlenmektedir. }\end{array}$ \\
\hline
\end{tabular}


Zenginlerin benlik sunumu, düz anlamda zengin iki erkek aktör ifade edilirken; yan anlamlarda moda takibi, uyum, pahalı ürün kullanımı, dış görünüşe önem verme, gece hayatının olması, zengin yaşam, hayat kalitesinin yüksek oluşu, elitlik, herkesçe bilinen pahalı markaların tercih edildiği gibi anlamlar ortaya çıkmaktadır.

\section{Sonuç}

Goffman'a göre bireyler seyircinin karşısına, kendileri ile özdeşen performanslar ile çıkmaktadırlar. Dolayısıyla aktörler, hayatlarının her alanında benlikler ortaya koymakta, diğer insanların takdirini kazanmayı beklemektedirler. Sunulan benlikler toplumun onayını amaçladığından, aktör için seyirci büyük önem taşımaktadır. Aktörün benlik sunumu sırasında göstermiş olduğu çaba, seyircinin benlik sunumu hakkındaki tutum ve inancını etkilemektedir. Goffman'ın kitabına benlik sunumu ve yayılan izlenim ile çizdiği kavramsal çerçeve, yeni medya iletişimi ile geleneksel yüz yüze iletişimi, karşılaştırma olanağı sağlamaktadır. Goffman'ın kuramına bakarak Instagram'daki hikâyelerin nasıl oluşturulduğu ve benliklerin nasıl sunulduğu konusuna 1şık tutmak mümkündür. Instagram kullanıcılarının, hikâyelerini ne amaçla ve nasıl oluşturduğunu soruşturmak, kullanıcıların benlik sunumlarını nasıl gerçekleştirdiklerini anlamamızı kolaylaştıracaktır. Bu çerçevede, çalışmada incelenen profiller ışığında kategoriler olușturulmuştur; Yeni annenin benlik sunumu, yeni evlinin benlik sunumu, alıșverișkoliklerin benlik sunumu, çok gezenlerin benlik sunumu, gösterișçilerin benlik sunumu, kendini gösterenlerin benlik sunumu, zenginlerin benlik sunumudur. Kategorilerin incelenmesinde kullanılan, Barthes'1n Göstergebilim yöntemi, hikâyelerdeki benlik sunumlarının nasıl gerçekleştirildiği ve ne anlatılmak istendiğinin anlaşılmasına kolaylık sağlamıştır. Goffman'ın yayılan izlenim ve Barthes'ın göstergebilim yöntemi 1şı̆̆ında incelenen profillerde Instagram uygulamasının, bir benlik sunma ve inşa etme aracı olarak kullanıldığı gözlenmiştir.

Sonuç olarak incelenen hikâye sunumlarına bakıldığında Goffman'ın savunduğu, birey performansını sunarken kendisini izleyenlerin beğenisi kazanmasına yönelik performansını idealize eder, düşüncesi haklı çıkmıştır. Instagram uygulamasında bireyler kendilerini nasıl göstermek, sunmak istiyorsa o yönde hikâye paylaşmaktadır. Bazen hikâyelerin arka planında benliklerine aykırı detaylar olduğu fark edilmektedir. Bu detaylar aynı zamanda farklı çalışmalar yapılması gerektiğini göstermektedir. Sunulan performanslardaki yanlış ifade denetimi ve yanlış sunumları içeren yepyeni bir çalışma bu alanın her yönüyle anlaşılması açısından önem taşır. Goffman'ın yayılan izlenim kuramı ve Barthes'ın göstergebilim yönteminin, sosyal paylaşım ağlarından biri olan Instagram örneklemi üzerinde son derece zengin veriler elde etmemizi sağladığı ortaya çıkmaktadır. Yayılan izlenim kuramı ve göstergebilim yöntemi çerçevesinde incelenen hikâyelere bakıldığında benlik sunumlarının ve ifade araçlarının birbirinden farklı olduğunu görebilmekteyiz. Dolayısıyla incelenen profillerin, bize sosyal medyada benlik oluşturma ve benlik sunma konularında hangi araçların kullanıldığı hakkında fikirler verdiğini söyleyebiliriz. Birey bir yandan hikâyesinin nasıl görünmesini istiyorsa o şekilde idealize etmekte; bir yandan da çeşitli göstergeler kullanarak benliğini ifade etmektedir. Goffman'ın deyimiyle hayat bir oyun sahnesidir ve aktörler oyunlarını seyircinin beğenisini kazanma yönünde hazırlamaktadır. Günümüzde bu performansların seyirciyle buluştuğu yeni alanlardan biri Instagram'dir. 


\section{Kaynakça}

Akbayır, Z. (2016).Bana Bir Hikâye Anlat: Marka İletişiminde Hikayeleştirme ve İnternet. Karadeniz Teknik Üniversitesi İletişim Fakültesi Elektronik Dergisi, 3(12), 68-69.

Akerson, E. F. (2005). Göstergebilime Giriş. İstanbul: Multilingual Yayınevi.

Barthes, R. (2014). Göstergebilimsel Serüven. (7.bs.). İstanbul: Yapı Kredi Yayınları.

Biçer, S. (2014). Goffman Metodolojisinden Hareketle Facebook Üzerinde Akademisyenlerin Kendini Sunma Davranışı. Adıyaman Üniversitesi Sosyal Bilimler Enstitüsü Dergisi, 7(16), 66-100.

Bilici, E.İ. (2016). Transmedia Storytelling and Transforming Human Imagination. Online Academic Journal of Information Technology, 7(23), 31-39.

Binark, M. (2007). Yeni Medya Çalışmaları. Ankara: Dipnot Yayınları.

Bircan, U. (2015). Roland Barthes ve Göstergebilim. Sosyal Bilimler Araştırma Dergisi, 13(26), $17-41$.

Bulunmaz, B. (2011). Yeni Medya Eki Medyaya Karşı: Savaşı Kim Kazand1 ya da Kim Kazanacak?. Karadeniz Teknik Üniversitesi İletişim Araştırmaları Dergisi, 4(7), 2229.

Çalık, D., Çınar, P. (2009). Geçmişten Günümüze Bilgi Yaklaşımları Bilgi Toplumu ve İnternet. Inet-tr'09 - XIV. Türkiye'de İnternet Konferans1 Bildirileri: 12-13 Aralık. İstanbul Bilgi Üniversitesi, (s.77-88), İstanbul.

Dedeoğlu, G. (2016).Teknoloji, İletişim, Yeni Medya ve Etik. (1.bs.). Bursa: Sentez Yayıncılık.

Dervişcemaloğlu, B. (2014). Anlatıbilimine Giriş. (1.bs.). İstanbul: Dergâh Yayınları.

Erdoğan, İ., Alemdar, K. (2010).Öteki Kuram. (3.bs.). İstanbul: Seçkin Yayıncılık.

Goffman, E. (2014). Günlük Yaşamda Benliğin Sunumu (B. Cezar, çev.) İstanbul: Metis Yayınları.

Gökaliler, E., Saatc1oğlu, E. (2016). Emoji Usage in Ads: A Research on Consumers'Advertising Attitudes Towards Emoji Advertising. Selçuk Üniversitesi Sosyal Bilimler Meslek Yüksekokulu Dergisi, 19(2), 63-91.

Günay, D. (2008). Görsel Okuryazarlık ve İmgenin Anlamlandırılması. Süleyman Demirel Üniversitesi Güzel Sanatlar Fakültesi Hakemli Dergisi, 1(1), 1-29.

Güney, E. (2014). Dijital Görsel Kültür ve Yeni Medya Ekseninde Sanatın Değiş̧en Rolü. Ondokuzmayıs Üniversitesi Sosyal Bilimler Enstitüsü Güzel Sanatlar Eğitimi Anabilim Dalı, Yayınlanmamış Doktora Tezi, Samsun.

Güzel, E. (2016). Dijital Kültür ve Çevrimiçi Sosyal Ağlarda Rekabetin Aktörü: 'Dijital Habitus'. Gümüşhane Üniversitesi İletişim Fakültesi Elektronik Dergisi, 4(1), 83-103.

Kırık, A.M. (2013). Sosyal Medya: "Sosyalleşen Birey”. Kırık, A.M. ve A. Büyükarslan (Ed.). Gelişen Web Teknolojileri ve Sosyal Medya Bağımlılığı (s.69-102). Konya: Çizgi Kitapevi Yayınları.

Kurtoğlu, R., Özbölük, T. (2016). Görsel İletişim Çağında Markaların Emojiye Adaptasyonu. Akademik Sosyal Araştırmalar Dergisi, 4(29), 144-155. 
Küngerü, A. (2016). Bir İfade Anlatma Aracı Olarak Dijital Öykü Anlatımı. Abant Kültürel Araştırmalar Dergisi, 1(2), 33-45.

Lotman, Y. (2012). Sinemada Göstergebilim (O. Özügül çev.). (3.bs.). Ankara: Nirengi Kitap.

Özdemir, Z. (2015). Sosyal Medyada Kimlik İnşasında Yeni Akım: Özçekim Kullanımı. Maltepe Üniversitesi İletişim Fakültesi Dergisi, 2(1), 112-131.

Sarıfakığ lu, B. (2007). İnternetin Toplumsal Etkileri. Elektrik Mühendisliği Dergisi, (431), 5456.

Sivas, A. (2012). Sinema ve Göstergebilim İlişkisi Üzerine Bir Deneme. İstanbul Ticaret Üniversitesi Sosyal Bilimler Dergisi, 11(21), 527-538.

Soncu, G.A. (2016). New Medium Where Selfs Are Offered for Admiration: Instagram. International Peer-Reviewed Journal of Communication and Humanties Research, (13), 214-233.

Soydaş, N., Yılmaz, B. (2016). Yeni İletişim Ortamlarında İçerik Oluşturma Aracı Olarak Dijital/ Görsel Hikâyecilik Anlatımı. 2.Uluslararası Medya Çalışmaları Kongresi: 20-23 Nisan. Antalya.

Talas, M., Bildirici, S.S. (2008). Farklı Yönleriyle Küreselleşme. (1.bs.). İstanbul: Doğu Kütüphanesi.

Turgut, G., Kışla, T. (2015). The Use of Computer-aided Story in Education: Literature Review. Turkish Online Journal of Qualitative Inquiry, 6(2), 97-121.

Vural, A.B. v.d. Bat, M. (2010). Yeni Bir İletişim Ortamı Olarak Sosyal Medya: Ege Üniversitesi İletişim Fakültesine Yönelik Bir Araştırma. Yaşar Üniversitesi Dergisi, 5(20), 3348-3382.

Yaylagül, L.(2014). Kitle İletişim Kuramları. (6. bs.). Ankara: Dipnot Yayınları.

Yengin, D. (2015). Yeni Medyanın Olanakları: Semantik Web. The Turkish Online Journal of Design, Art and Communication, 5(1), 44-53.

Yılmaz, A. (2004). İkinci Küreselleşme Dalgası 'Kavram, Süreç, Sorunlar”. (1. bs.). İstanbul: Vadi Yayınları. 
Instagram Örneği Üzerinden Sosyal Medyada Hikâye Anlatıcılığı

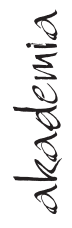

